\title{
Synthesis and evaluation of $\alpha$-hydroxy fatty acid-derived heterocyclic compounds with potential industrial interest
}

\author{
By A. M. F. Eissa and R. El-Sayed \\ Chemistry Department, Faculty of Science, Benha University, Benha - Egypt. \\ E-mail: ref_at@ hotmail.com
}

\section{RESUMEN}

Síntesis y evaluación de compuestos heterocíclicos derivados de $\alpha$-hidroxi ácidos grasos con interés industrial potencial

El cloruro del ácido 2-hidroxiheptadecanoico (2) reaccionó con el ácido antranílico para producir 3,1-benzoxazin-4-onas 2sustituidas que fueron usadas como material de partida en la síntesis de compuestos heterocíclicos condensados y no condensados por reacción con nucleófilos nitrogenados, como la hidracina o la formamida. Los productos fueron hechos reaccionar con diferentes moles de óxido de propileno $(n=5,10$ 15) para producir un grupo nuevo de compuestos no-iónicos teniendo una doble función como antibacterianos y tensoactivos que pueden ser usados en la manufactura de medicamentos, cosméticos, pesticidas, o pueden ser usados como aditivos antibacterianos y/o antifúngicos. Se determinaron diversas propiedades físicas de los compuestos preparados así como sus efectos antimicrobianos y sus biodegrabilidad.

PALABRAS-CLAVE: Derivados heterocíclicos - Propiedades antimicrobianas - Propiedades físicas - Tensioactivos

\section{SUMMARY}

Synthesis and evaluation of $\alpha$-hydroxy fatty acidderived heterocyclic compounds with potential industrial interest

T2-Hydroxyheptadecanoic acid chloride (2) reacted with anthranilic acid to produce 2-substituted-3,1-benzoxazin-4-one (3) which was used as starting material to synthesize some condensed and non-condensed heterocyclic compounds by reaction with nitrogen nucleophiles e.g., hydrazine hydrate, and formamide. The products were subjected to reaction with different moles of propylene oxide $(n=5,10,15)$ to produce a novel group of nonionic compounds having a double function as antibacterial and surface active agents which can be used in the manufacturing of drugs, cosmetics, pesticides or can be used as antibacterial and/or antifungal additives. The surface active properties as surface and interfacial tension, cloud point, foaming height, wetting time, and emulsification power were determined, the antimicrobial and biodegradability were also screened.

KEY-WORDS: Antimicrobial properties - Heterocyclic derivatives - Physical properties - Surface active agents

\section{INTRODUCTION}

Varied biological activities have been attributed to 2-substituted-3,1-benzoxazin-4-ones (Madkour, 2005) as well as the corresponding quinazoline derivatives including antipyretic (El-Sayed et al., 2005;
Amin, 1998), antiinflammatory agents (Amin et al., 1998), antimitotic, anticancer agents (Aly, 2003) and they also have good storage stability in detergents (Mohamed et al., 2003). This led us to synthesize a new series of 4H-3,1-benzoxazin-4-one and corresponding quinazoline derivatives which have high expectations for pharmaceutical and industrial applications. This encouraged us to synthesize a novel group of nonionic surface active agents containing the nucleus from $\alpha$-hydroxy fatty acid. The synthesized compounds which have an active hydrogen atom were subjected to react with propylene oxide with different moles $(n=5,10,15)$ to produce a novel group of nonionic compounds having a double function as antimicrobial and surface active agents which can be useful in the manufacturing of drugs, cosmetics, pesticides or can be use as antibacterial and/or antifungal additives. The surface properties as surface and interfacial tension, cloud point, foaming height, wetting time, and emulsification power were determined. The biodegradability and the antimicrobial were also screened.

\section{MATERIALS AND METHODS}

Melting points are uncorrected. IR spectra in $\mathrm{KBr}$ were measured on a Pye-Uncam SP-1000 infrared spectrophotometer on a $\mathrm{KBr}$ disk or nujol. The ${ }^{1} \mathrm{H}$ NMR spectra were obtained on a Varian EM-390-60 $\mathrm{MHz}$ spectrometer in DMSO as the solvent Tetramethylsilane TMS served as an internal reference and chemical shifts are expressed as $\delta$ (ppm). Mass spectra were recorded on a GC/MS Finning-MAT. Microanalyses were preformed by the Micro analytical Unit at Cairo University. All the compounds gave satisfactory elemental analyses. Thin layer chromatography (TLC) was carried out on silica gel (MN-Kieselgel G., $0.2 \mathrm{~mm}$ thickness) and the plates were scanned under $254 \mathrm{~nm}$ ultraviolet light. Antimicrobial and antifungal activity testes were carried out at the microbiology Lab., Faculty of Science, Benha University, Egypt.

\subsection{Synthesis of 2-(1-Hydroxyheptadecyl)- 1,3-benzoxazin-4-one (3)}

A solution of acid chloride $2(0.01 \mathrm{~mol})$ and anthranilic acid $(0.01 \mathrm{~mol})$ in dry pyridine $(30 \mathrm{ml})$ 
was refluxed for $3 \mathrm{~h}$., the reaction mixture was cooled and poured into cold diluted $\mathrm{HCl}$. The solid that separated was filtered off and recrystallized from toluene to give 3 (Scheme 1). Yield, $80 \%$, $\mathrm{mp}=86-88^{\circ} \mathrm{C}$. IR: $v=3420(\mathrm{OH}), 2910-2860(\mathrm{CH}$ aliphatic), 3014 ( $\mathrm{CH}$ aromatic), 1681 (CO) and 1589 $\mathrm{cm}^{-1}(\mathrm{C}=\mathrm{N}) .{ }^{1} \mathrm{H}$ NMR $\left(\mathrm{CDCl}_{3}\right): \delta=0.96\left(\mathrm{t}, 3 \mathrm{H}, \mathrm{CH}_{3}\right)$, 1.29-1.33 (m, 30H, $\left.\mathrm{CH}_{2}\right), 3.2(\mathrm{~s}, 1 \mathrm{H},-\mathrm{CH}-\mathrm{OH}), 7.5-$ $8.1(\mathrm{~m}, 4 \mathrm{H}, \mathrm{ArH})$ and $9.7(\mathrm{~s}, 1 \mathrm{H}, \mathrm{OH}) . \mathrm{MS}: \mathrm{m} / \mathrm{z}(\%)$ shows no molecular ion peak but shows ion peak $\mathrm{m} / \mathrm{z}=357(59.9 \%)$ corresponding to $\left(\mathrm{M}^{+}-\mathrm{CO}_{2}\right)$, and the base peak at $\mathrm{m} / \mathrm{z}=59(100 \%)$. Anal. Calcd for $\mathrm{C}_{25} \mathrm{H}_{39} \mathrm{NO}_{3}$ (401.59): C, 74.77; $\mathrm{H}, 9.79 ; \mathrm{N}, 3.49$ $\%$. Found C, 74.86; H, 9.93; N, $3.62 \%$.

\subsection{Synthesis of 2-(1-Hydroxyheptadecyl)- quinazolin-4(3H)-one (4)}

A mixture of compound $3(0.01 \mathrm{~mol})$ and formamide $(0.015 \mathrm{~mol})$ was refluxed for $3 \mathrm{~h}$ in boiling ethanol $(30 \mathrm{ml})$, then poured into water. The separated solid after concentration and cooling was filtered off and crystallized from ethanol to give $\mathbf{4}$
(Scheme 1). Yield $76 \%, \mathrm{mp}=75-77^{\circ} \mathrm{C}$, IR: $v=3450$ $(\mathrm{OH}), 3320(\mathrm{NH}), 2920-2850$ (CH aliphatic), 1680 $\mathrm{cm}^{-1}(\mathrm{CO}) .{ }^{1} \mathrm{H}$ NMR $\left(\mathrm{CDCl}_{3}\right): \delta=0.95\left(\mathrm{t}, 3 \mathrm{H}, \mathrm{CH}_{3}\right)$, 1,2-1,3 $\left(\mathrm{m}, 30 \mathrm{H}, \mathrm{CH}_{2}\right.$ in chain), $3.3(\mathrm{~s}, 1 \mathrm{H},-\mathrm{CH}-\mathrm{OH})$, 8.2 (brs, $1 \mathrm{H}, \mathrm{NH}), 7.3-7.8(\mathrm{~m}, 4 \mathrm{H}, \mathrm{ArH})$ and 9.7 (brs, $1 \mathrm{H}, \mathrm{OH}$ ). Anal. Calcd for $\mathrm{C}_{25} \mathrm{H}_{40} \mathrm{~N}_{2} \mathrm{O}_{2}$ (400.61): C, 74.96; H, 10.06; N, 6.99 \%. Found C, 75.12; H, 10.13; N, $7.21 \%$.

\subsection{Synthesis of 3-(2-Chloroacety)-2- (1-hydroxyheptadecyl)-quinazolin-4(3H) -one (5)}

A mixture of 4 (0.01 mole) and chloroacetyl chloride (0.01 mole) was refluxed in boiling $\mathrm{N}$, $\mathrm{N}$-dimethylformamide (DMF) $(30 \mathrm{ml})$ for $3 \mathrm{~h}$. Then the mixture was poured into water. The precipitated solid was filtered off, dried and crystallized from benzene to give 5 (Scheme 1). Yield $76 \%, \mathrm{mp}=93-$ $95^{\circ} \mathrm{C}$. IR: $v=3456(\mathrm{OH}), 2920-2850$ ( $\mathrm{CH}$ aliphatic), 1671, 1699 (CO), $1600 \mathrm{~cm}^{-1}(\mathrm{C}=\mathrm{N}) .{ }^{1} \mathrm{H}$ NMR: $\left(\mathrm{CDCl}_{3}\right)$ $\delta^{\prime}=0.9\left(\mathrm{t}, 3 \mathrm{H}, \mathrm{CH}_{3}\right), 1.25-1.33\left(\mathrm{~m}, 30 \mathrm{H}, \mathrm{CH}_{2}\right.$ of alkyl chain), 4.25 (s, 2H, $\mathrm{CH}_{2}$ ), $3.2(\mathrm{~s}, 1 \mathrm{H}, \mathrm{CH}-\mathrm{OH})$, 7.5-<smiles>[R]c1nc2ccccc2c2ccccc12</smiles>

Scheme 1 
$7.9(\mathrm{~m}, 4 \mathrm{H}, \mathrm{ArH})$, and 2.0 (s, 1H, OH). Anal. Calcd for $\mathrm{C}_{27} \mathrm{H}_{41} \mathrm{CIN}_{2} \mathrm{O}_{3}$ (477.09): $\mathrm{C}, 67.97 ; \mathrm{H}, 8.66 ; \mathrm{N}$, $7.43 \%$. Found C, 67.82; $\mathrm{H}, 8.51 ; \mathrm{N}, 7.56 \%$.

\subsection{Synthesis of 3-(2-Hydrazino-acetyl)-2- (1-hydroxyheptadecyl)-quinazolin-4(3H) -one (6)}

A mixture of 5 ( 0.01 mole) and hydrazine hydrate ( 0.015 mole) was heated in boiling ethanol $(30 \mathrm{ml})$ under reflux for $4 \mathrm{~h}$. Then the mixture was poured into water. The precipitated solid was filtered off, dried and crystallized from ethanol to give 6 (Scheme 1). Yield $76 \%, m p=110-112{ }^{\circ} \mathrm{C}$. IR: $v=$ $3380,1680,1670$ and $1625 \mathrm{~cm}^{-1}$ attributable to $(\mathrm{OH}),\left(\mathrm{CO}\right.$ of two carbonyl groups), $(\mathrm{C}=\mathrm{N}) .{ }^{1} \mathrm{H}$ NMR: $\left(\mathrm{CDCl}_{3}\right) \delta^{\prime}=0.96\left(\mathrm{t}, 3 \mathrm{H}, \mathrm{CH}_{3}\right), 1.29-1.53(\mathrm{~m}, 30 \mathrm{H}$, $\mathrm{CH}_{2}$ of alkyl chain), $3.55\left(\mathrm{~s}, 2 \mathrm{H}, \mathrm{CH}_{2}\right), 3.2(\mathrm{~s}, 1 \mathrm{H}$, $\mathrm{CH}-\mathrm{OH}), 7.5-7.9(\mathrm{~m}, 4 \mathrm{H}, \mathrm{ArH}), 7.2(\mathrm{brs}, 1 \mathrm{H}, \mathrm{NH})$ and $2.0(\mathrm{~s}, 1 \mathrm{H}, \mathrm{OH}) . \mathrm{MS}: \mathrm{m} / \mathrm{z}(\%)$ shows a molecular ion peak at $\mathrm{M}^{+}=472(44.12 \%)$. Anal. Calcd for $\mathrm{C}_{27} \mathrm{H}_{44} \mathrm{~N}_{4} \mathrm{O}_{3}$ (472.68): C, 68.61; H, 9.38; N, $11.85 \%$. Found C, 68.75; H, 9.49; N, $11.97 \%$.

\subsection{Synthesis of 6-(1-hydroxyheptadecyl)- 2,3-dihydro-[1,2,4]triazino[4,3-c]quin- azolin-4-one (7)}

Heating of the hydrazino derivative 6 above its melting point by fusion in an oil bath for $2 \mathrm{~h}$. After cooling water was added and the solid obtained filtered off and crystallized from xylene to give 7 (Scheme 1). Yield $62 \%, \mathrm{mp}=76-78^{\circ} \mathrm{C}$ IR: $v=3340$ $(\mathrm{OH}), 3320(\mathrm{NH}), 2920-2850$ ( $\mathrm{CH}$ aliphatic), 1689 (CO), and $1590 \mathrm{~cm}^{-1}(\mathrm{C}=\mathrm{N})$. The UV: $\lambda_{\text {mas }} 280 \mathrm{~nm}$ $(\varepsilon=3700)$ attributed to 1,2,4-triazinone nucleus (Cansiz et al., 2004). 'H NMR: $\left(\mathrm{CDCl}_{3}\right) \delta^{\prime}=0.95$ (t, $\left.3 \mathrm{H}, \mathrm{CH}_{3}\right), 1.29-1.33\left(\mathrm{~m}, 30 \mathrm{H}, \mathrm{CH}_{2}\right.$ of alkyl chain), $3.54\left(\mathrm{~s}, 2 \mathrm{H}, \mathrm{CH}_{2}\right), 3.2(\mathrm{~s}, 1 \mathrm{H}, \mathrm{CH}-\mathrm{OH}), 7.3-7.7(\mathrm{~m}$, $4 \mathrm{H}, \mathrm{ArH}), 7.0$ (brs, $1 \mathrm{H}, \mathrm{NH})$ and $2.0(\mathrm{~s}, 1 \mathrm{H}, \mathrm{OH})$. MS: $\mathrm{m} / \mathrm{z}(\%)$ shows a molecular ion peak at $\mathrm{M}^{+}=454$ (4.12\%). Anal. Calcd for $\mathrm{C}_{27} \mathrm{H}_{42} \mathrm{~N}_{4} \mathrm{O}_{2}$ (454.66): C, 71.33; $\mathrm{H}, 9.31 ; \mathrm{N}, 12.32 \%$. Found C, 71.22; H, 9.26; N, $12.47 \%$.

\subsection{Synthesis of 3-Amino-2-(1- hydroxyheptadecyl)-quinazolin-4(3H)- one (8)}

A solution of 3 ( 0.01 mole) in dry benzene (30 $\mathrm{ml})$ and hydrazine hydrate $(0.015$ mole) was heated under reflux for $4 \mathrm{~h}$. Then the mixture was poured into water. The precipitated solid was filtered off, dried and crystallized from ethanol to give 8 (Scheme 1). Yield $78 \%, m p=92-94{ }^{\circ} \mathrm{C}$. IR: $v=3350$ $(\mathrm{OH}), 3329(\mathrm{NH}), 2921-2849(\mathrm{CH}$ aliphatic),1690 (CO), and $1600 \mathrm{~cm}^{-1}(\mathrm{C}=\mathrm{N}) .{ }^{1} \mathrm{H}$ NMR: $\left(\mathrm{CDCl}_{3}\right) \delta^{\prime}=$ $0.95\left(\mathrm{t}, 3 \mathrm{H}, \mathrm{CH}_{3}\right), 1.29-1.33\left(\mathrm{~m}, 30 \mathrm{H}, \mathrm{CH}_{2}\right.$ of alkyl chain), 3.1 (s, 1H, CH-OH), 7.4-7.9 (m, 4H, ArH), 8.2 (brs, $1 \mathrm{H}, \mathrm{NH}$ ) and $9.5(\mathrm{~s}, 1 \mathrm{H}, \mathrm{OH})$. Anal. Calcd for $\mathrm{C}_{25} \mathrm{H}_{41} \mathrm{~N}_{3} \mathrm{O}_{2}$ (415.62): C, 72.25; H, 9.94; N, 10.11\%. Found C, 72.16; H, 9.88; N, 10.04\%.

\subsection{Synthesis of 3 -chloro-N-[2-(1- hydroxyheptadecyl)-4-oxo-quinazolin- 3(4H)-yl]-acetamide (9)}

A solution of 8 (0.01 mole), was allowed to react with chloroacetyl chloride $(0.01$ mole) in refluxing pyridine about $2 \mathrm{~h}$, then poured over ice $/ \mathrm{HCl}$. The product was filtered and crystallized from toluene to give 9 (Scheme 1). Yield $65 \%, \mathrm{mp}=105-107^{\circ} \mathrm{C}$. IR: $v=3338-3170(\mathrm{OH}$ and $\mathrm{NH}), 2920-2850(\mathrm{CH}$ aliphatic), and 1694, $1666 \mathrm{~cm}^{-1}$ (CO). ${ }^{1} \mathrm{H}$ NMR: $\delta=0.85\left(\mathrm{t}, 3 \mathrm{H}, \mathrm{CH}_{3}\right), 1.2-1.5\left(\mathrm{~m}, 30 \mathrm{H}, \mathrm{CH}_{2}\right.$ of alkyl chain), $3.4(\mathrm{~s}, 1 \mathrm{H}, \mathrm{CH}-\mathrm{OH}), 4.24\left(\mathrm{~s}, 2 \mathrm{H}, \mathrm{CH}_{2}\right), 7.3-$ $7.8(\mathrm{~m}, 4 \mathrm{H}, \mathrm{ArH}), 8.0$ and $9.3(\mathrm{~s}, 3 \mathrm{H}, \mathrm{NH})$ and 9.7 (s, $1 \mathrm{H}, \mathrm{OH}) . \mathrm{MS}: \mathrm{m} / \mathrm{z}(\%)$ shows a molecular ion peak at $\mathrm{M}^{+}=492(54.1 \%)$. Anal. Calcd for $\mathrm{C}_{27} \mathrm{H}_{42}$ $\mathrm{ClN}_{3} \mathrm{O}_{3}$ (492.11): C, 65.90; $\mathrm{H}, 8.60 ; \mathrm{Cl}, 7.20 ; \mathrm{N}, 8.54$ $\%$. Found $\mathrm{C}, 66.11 ; \mathrm{H}, 8.74 ; \mathrm{Cl}, 7.34 ; \mathrm{N}, 8.71 \%$.

\subsection{Synthesis of 6-(1-hydroxyheptadecyl)- $2 \mathrm{H}-[1,2,4]$ triazino[2,3-c]quinazolin-3(4H)- one (10)}

A solution of compound 8 (0.01 mole) and ammonium acetate $(0.01$ mole) in acetic acid $(30 \mathrm{ml})$ was refluxed for $3 \mathrm{~h}$, then poured into water. The separated solid after concentration and cooling was filtered off and crystallized from ethanol to give $\mathbf{1 0}$ (Scheme 1). Yield $75 \%, \mathrm{mp}=73-75^{\circ} \mathrm{C}$. IR: $v=3430$ $(\mathrm{OH}), 3230(\mathrm{NH}), 2870-2980(\mathrm{CH}), 1660(\mathrm{CO})$ and $1605 \mathrm{~cm}^{-1}(\mathrm{C}=\mathrm{N}) \cdot{ }^{1} \mathrm{H}$ NMR: $\left(\mathrm{CDCl}_{3}\right) \delta^{\prime}=0.96(\mathrm{t}, 3 \mathrm{H}$, $\left.\mathrm{CH}_{3}\right), 1.29-1.33\left(\mathrm{~m}, 30 \mathrm{H}, \mathrm{CH}_{2}\right.$ of alkyl chain), 4.40 (s, $\left.2 \mathrm{H}, \mathrm{CH}_{2}\right), 3.2(\mathrm{~s}, 1 \mathrm{H}, \mathrm{CH}-\mathrm{OH})$, 7.3-7.6 (m, $\left.4 \mathrm{H}, \mathrm{ArH}\right)$, 8.0 (brs, $1 \mathrm{H}, \mathrm{NH}$ ) and $2.0(\mathrm{~s}, 1 \mathrm{H}, \mathrm{OH}) . \mathrm{MS}: \mathrm{m} / \mathrm{z}(\%)$ shows a molecular ion peak at $\mathrm{M}^{+}=454(44.11 \%)$. Anal. Calcd for $\mathrm{C}_{27} \mathrm{H}_{42} \mathrm{~N}_{4} \mathrm{O}_{2}$ (454.66): $\mathrm{C}, 71.33 ; \mathrm{H}, 9.31$; $\mathrm{N}, 12.32 \%$. Found C, 71.55; H, 9.42; N, $12.25 \%$.

\subsection{Synthesis of 6-(1-hydroxyheptadecyl)-3,4- dihydro-[1,2,4]triazino[2,3-c]quinazolin-2- one (11)}

A solution of compound 8 (0.01 mole) and chloroacetamide $(0.015$ mole) was refluxed for $3 \mathrm{~h}$ in boiling N,N-dimethylformamide (DMF) (30 ml). Then the mixture was poured into water. The precipitated solid was filtered off, dried and crystallized from ethanol to give 11 (Scheme 1). Yield $75 \%, \mathrm{mp}=75$ $77^{\circ} \mathrm{C}$. UV: $\lambda_{\max }=330$ (450), 314 (1450), 280 (3600), 266 (830) and 255 (600). Bands of this type are exhibit with all fused aromatic azo compounds (Eissa, 2003). ${ }^{1} \mathrm{H}$ NMR: $\left(\mathrm{CDCl}_{3}\right) \delta^{\prime}=0.96\left(\mathrm{t}, 3 \mathrm{H}, \mathrm{CH}_{3}\right), 1.29-1.33(\mathrm{~m}$, $30 \mathrm{H}, \mathrm{CH}_{2}$ of alkyl chain), $3.2(\mathrm{~s}, 1 \mathrm{H}, \mathrm{CH}-\mathrm{OH}), 3.70$ (s, $\left.2 \mathrm{H}, \mathrm{CH}_{2}\right), 7.3-7.6(\mathrm{~m}, 4 \mathrm{H}, \mathrm{ArH}), 8.0(\mathrm{~s}, 1 \mathrm{H}, \mathrm{NH})$ and 9.5 (s, $1 \mathrm{H}, \mathrm{OH}$ ). Anal. Calcd for $\mathrm{C}_{27} \mathrm{H}_{42} \mathrm{~N}_{4} \mathrm{O}_{2}$ (454.66): C, 71.33; H, 9.31; N, $12.32 \%$. Gave C, 71.49; H, 9.24; N, $12.23 \%$.

\subsection{Synthesis of 1-[2-(1-hydroxyheptadecyl)- 4-oxo-quinazolin-3(4H)-yl]-3-phenyl- thiourea (12)}

A solution of compound 8 (0.01 mole) and phenyl isothiocyanate $(0.01$ mole) was refluxed in 
boiling benzene $(30 \mathrm{ml})$ for $3 \mathrm{~h}$, then concentrated and crystallized from butanol to give 12 (Scheme 1). Yield $65 \%, \mathrm{mp}=107-109{ }^{\circ} \mathrm{C}$. IR: $v=3440$, 3380$3200,2960-2870,1670,1620$ and $1230 \mathrm{~cm}^{-1}$ due to $(\mathrm{OH})$, ( $\mathrm{NH}$ nonbonding and bonded), $(\mathrm{CH}),(\mathrm{CO})$, $(\mathrm{C}=\mathrm{N})$ and $(\mathrm{CS})$ respectively. ${ }^{1} \mathrm{H} \mathrm{NMR}\left(\mathrm{CDCl}_{3}\right): \delta=0.9$ (t, $\left.3 \mathrm{H}, \mathrm{CH}_{3}\right), 1,2-1,3\left(\mathrm{~m}, 30 \mathrm{H}, \mathrm{CH}_{2}\right.$ in chain), 3.1 (s, $1 \mathrm{H}, \mathrm{CH}-\mathrm{OH}), 4.8$ (brs, $1 \mathrm{H}, \mathrm{NH}), 6.46-7.9(\mathrm{~m}, 4 \mathrm{H}, \mathrm{ArH})$ and $9.5(\mathrm{~s}, 1 \mathrm{H}, \mathrm{OH})$. Anal. Calcd for $\mathrm{C}_{32} \mathrm{H}_{46} \mathrm{~N}_{4} \mathrm{O}_{2} \mathrm{~S}$ (550.81): C, 69.78; H, 8.42; N, 10.17; S, $5.82 \%$. Found C, 69.89; H, 8.66; N, 10.25; S, $5.96 \%$.

\subsection{Synthesis of 3-(2-(1-hydroxyheptadecyl)- 4-oxoquinazolin-3(4H)-yl)-1-phenyl-2- thioxo-dihydropyrimidine-4,6-dione (13)}

A solution of 12 (0.01 mole) and malonic acid $(0.01 \mathrm{~mole})$ in acetylchloride $(40 \mathrm{ml})$ was refluxed for $3 \mathrm{~h}$, then poured into water. The separated solid was filtered off and crystallized from benzene to give 13 (Scheme 1). Yield $60 \%, m p=81-83^{\circ} \mathrm{C}$. The IR: $v=3450,2950-2860,1660,1640$ and 1310 $\mathrm{cm}^{-1}$ due to $(\mathrm{OH}),(\mathrm{CH}$ aliphatic), (CO of two carbonyl groups) and (CS) respectively. ${ }^{1} \mathrm{H}$ NMR $\left(\mathrm{CDCl}_{3}\right): \delta=0.9\left(\mathrm{t}, 3 \mathrm{H}, \mathrm{CH}_{3}\right), 1,2-1,3\left(\mathrm{~m}, 30 \mathrm{H}, \mathrm{CH}_{2}\right.$ in chain), $3.12\left(\mathrm{~s}, 2 \mathrm{H}, \mathrm{CH}_{2}\right), 3.2(\mathrm{~s}, 1 \mathrm{H}, \mathrm{CH}-\mathrm{OH}), 7.0-7.9$ $(\mathrm{m}, 4 \mathrm{H}, \mathrm{ArH})$ and $9.5(\mathrm{~s}, 1 \mathrm{H}, \mathrm{OH})$. MS: $\mathrm{m} / \mathrm{z}(\%)$ shows a molecular ion peak at $\mathrm{M}^{+}+1=619.8(34.16 \%)$. Anal. Calcd for $\mathrm{C}_{35} \mathrm{H}_{46} \mathrm{~N}_{4} \mathrm{O}_{4} \mathrm{~S}$ (618.85): C, 67.93; H, 7.49; N, $9.05 \%$. Found C, 67.82; H, 7.58; N, $9.18 \%$.

\subsection{Synthesis of $\mathrm{N}-(2-(1-h y d r o x y h e p t a d e c y l)-$ 4-oxoquinazolin-3(4H)-yl)benzamide (14)}

A solution of 8 ( 0.01 mole) and benzoyl chloride (0.01 mole) in dry acetone $(30 \mathrm{ml})$ was refluxed for $3 \mathrm{~h}$. Excess solvent was removed and the solid obtained was crystallized from suitable solvent to obtain 14 (Scheme 1). Yield $65 \%, m p=102-104^{\circ} \mathrm{C}$. IR: $v=3410,3320,1670,1650$ and $1620 \mathrm{~cm}^{-1}$ attributable to $(\mathrm{OH}),(\mathrm{NH}),(\mathrm{CO}$ of two carbonyl groups) and $(\mathrm{C}=\mathrm{N}) .{ }^{1} \mathrm{H}$ NMR: $\delta=0.95\left(\mathrm{t}, 3 \mathrm{H}, \mathrm{CH}_{3}\right)$, 1.2-1.3 (m, 30H, $\left.\mathrm{CH}_{2}\right), 3.1(\mathrm{~s}, 1 \mathrm{H}, \mathrm{CH}-\mathrm{OH}), 7.4-7.9$ $(\mathrm{m}, 9 \mathrm{H}, \mathrm{ArH}), 8.3(\mathrm{~s}, 3 \mathrm{H}, \mathrm{NH})$ and $9.7(\mathrm{~s}, 1 \mathrm{H}, \mathrm{OH})$. Anal. Calcd for $\mathrm{C}_{27} \mathrm{H}_{43} \mathrm{~N}_{3} \mathrm{O}_{3}$ (457.66): C, 70.86; $\mathrm{H}$, $9.47 ; \mathrm{N}, 9.18 \%$. Found C,70.91; H, 9.51; N, $9.12 \%$.

\subsection{Synthesis of 1-(2-phenyl- $[1,2,4]$ triazolo[1,5-c]quinazolin-5- yl)heptadecan-1-ol (15).}

A solution of 14 (0.01 mole) with ammonium acetate $(0.01 \mathrm{~mole})$ in acetic acid $(30 \mathrm{ml})$ was heated under reflux for $3 \mathrm{~h}$, then poured into water. The separated solid after concentration and cooling was filtered off and crystallized from butanol to give 15 (Scheme 1). Yield $60 \%, \mathrm{mp}=78-80{ }^{\circ} \mathrm{C}$. IR: 3430 (OH), 2910-2860 (CH aliphatic), 3050 (CH aromatic) and $1589 \mathrm{~cm}^{-1}(\mathrm{C}=\mathrm{N}) .{ }^{1} \mathrm{HNMR}: \delta=0.95\left(\mathrm{t}, 3 \mathrm{H}, \mathrm{CH}_{3}\right)$, 1.3-1.7 (m, 30H, $\left.\mathrm{CH}_{2}\right), 4.3(\mathrm{~s}, 1 \mathrm{H}, \mathrm{CH}-\mathrm{OH}), 7.32-8.11$ $(\mathrm{m}, 9 \mathrm{H}, \mathrm{ArH})$ and $2.0(\mathrm{~s}, 1 \mathrm{H}, \mathrm{OH})$. MS: $\mathrm{m} / \mathrm{z}(\%)$ shows a molecular ion peak at $\mathrm{M}^{+}=438(37.16 \%)$ Anal.
Calcd for $\mathrm{C}_{27} \mathrm{H}_{42} \mathrm{~N}_{4} \mathrm{O}$ (438.66): C, 73.93; $\mathrm{H}, 9.65 ; \mathrm{N}$, $12.77 \%$. Found C, 73.81; H, 9.81; N, $12.89 \%$.

\subsection{Conversion of the prepared compounds $(3-15)$ to nonionic surfactants (16-28)}

The processes were completed as described previously by Amin (2004). The accurate amount of propylene oxide taken up and the average degree of propenoxylation ( $n$ ) was determined from the increased mass of the reaction mixture and confirmed by a spectroscopic tool. The addition of propylene oxide gave a homologues mixture of propenoxylated products which were confirmed by IR and showed, two broad bands at 1100 and $950 \mathrm{~cm}^{-1}$ characteristic of $\mathrm{vC}-\mathrm{O}-\mathrm{C}$ ether linkage of polypropenoxy chain, besides the original bands of the compound and ${ }^{1} \mathrm{H}$ NMR showed, the protons of the propenoxy group $\delta=3.2-3.7\left(\mathrm{~m}, \mathrm{CH}_{2} \mathrm{CH}\left(\mathrm{CH}_{3}\right)-\mathrm{O}\right)$ besides the other protons of the compound.

\subsection{Determination of physical properties}

\subsubsection{Surface and interfacial tension}

Surface and interfacial tension were measured using Du-Nouy tensiometer (Findly, 1963) (Kruss, Type 8451) with $0.1 \mathrm{wt} \%$ aqueous solution at room temperature $\left(25^{\circ} \mathrm{C}\right)$

\subsubsection{Cloud point}

Cloud point was determined by gradually heating 1.0 wt $\%$ solution in a controlled temperature bath and recording the time at which the clear, or nearly clear solutions became definitely turbid. The reproducibility of this temperature was checked by cooling the solutions until they become clear again (Wiel et al., 1963).

\subsubsection{Wetting time}

Wetting time was determined by immersing a sample of cotton fabric in a $1.0 \mathrm{wt} \%$ aqueous solution of surfactants (Draves et al., 1931).

\subsubsection{Foaming properties}

Foaming properties were measured according to (El-Sukkary et al., 1987). In this procedure a 25 $\mathrm{ml}$ solution (1.0 wt \%) was shaken vigorously for 10 seconds in a $100 \mathrm{ml}$ glass stopper, graduated cylinder, at $25^{\circ} \mathrm{C}$. the solution was allowed to stand for 30 seconds, and the foam height was measured.

\subsubsection{Emulsification stability}

Emulsification stability was prepared from $10 \mathrm{ml}$ of a $20 \mathrm{~m}$ mol. aqueous solution of surfactant and $5 \mathrm{ml}$. of toluene at $40 \mathrm{C}$. The emulsifying property was determined by the time it took for an aqueous volume 
separating from the emulsion layer to reach $9 \mathrm{ml}$. counting from the moment the shaking was stopped (Takeshi, 1970).

\subsection{Biodegradability}

Surface tension measurements were made periodically each day, on each sample during the degradation test. Biodegradation (Eter et al., 1974) percent (D) for each sample was calculated using the following formula: $D=\left[\left(\gamma_{t}-\gamma_{0}\right)\left(\gamma_{b t}-\gamma_{0}\right)\right] \times 100$, where $\gamma_{t}=$ surface tension at time $t, \gamma_{0}=$ surface tension at zero time, $\gamma_{\mathrm{bt}}=$ surface tension of blank experiment at time $t$ (without samples).

\subsection{Biological activity}

The antimicrobial activities of some synthesized compounds were determined in vitro using the hole plate and filter paper disc method (Rosen, 1989) Different species of Gram positive and Gram negative bacteria in addition to some fungal plant pathogens were used. The compounds in question were dissolved in $10 \%$ acetone and different concentrations were chosen $(125,250,500 \mu \mathrm{g} / \mathrm{ml})$. Agar plates were surface inoculated uniformly from fresh broth culture of Gram +ve, Gram -ve bacteria and fungi. The disks were incubated at $28^{\circ} \mathrm{C}$ for $24 \mathrm{~h}$. the formed inhibition zones were measured in $\mathrm{mm}$.

\section{RESULTS AND DISCUSSION}

\subsection{Synthesis}

2-(1-Hydroxyheptadecyl)-1,3-benzoxazin-4-one (3) were constructed from the preparation of 2hydroxyheptadecanoic acid from the corresponding pure acid 1 according to procedures described in Eissa et al. (2003), followed by the synthesis of corresponding fatty acid chloride (Amin, 2004), which reacted with anthranilic acid in pyridine to give 3. The reaction of $\mathbf{3}$ with formamide or fusion with ammonium acetate at $150{ }^{\circ} \mathrm{C}$ gave 2-(1hydroxyheptadecyl)-3H-quinazolin-4-one (4).

The interaction between 4 and chloroacetyl chloride in dimethylformamide gave 3-(2-chloroacety)2-(1-hydroxyheptadecyl)-3H-quinazolin-4-one (5) which converted to the corresponding hydrazino derivative $\mathbf{6}$ via its interaction with hydrazine hydrate in boiling butanol. The hydrazino derivative 6 was cyclized by fusion above its melting point to 6-(1hydroxyheptadecyl)-2,3-dihydro-[1,2,4]triazino[4,3c]quinazolin-4-one (7).

Compound 3 reacted with hydrazine hydrate to give amino quinazolinone derivative 8 which was allowed to react with chloroacetyl chloride in refluxing pyridine to give 3-chloro- $\mathrm{N}-[2-(1-h y d r o x y h e p t a d e c y l)-$ 4-oxo-4H-quinazolin-3-yl]acetamide (9) which was treated by ammonium acetate-acetic acid to give 6(1-hydroxyheptadecyl)-2H-[1,2,4]triazino[2,3c]quinazolin-3(4H)-one (10). On the other hand, the reaction of 8 with chloroacetamide in boiling $N, N$ dimethyl formamide gave 6-(1-hydroxyheptadecyl)3,4-dihydro-[1,2,4]triazino[2,3-c]quinazolin-2one (11). Similarly, compound 8 was submitted to react with phenyl isothiocyanate in benzene, yielding 1-[2-(1-hydroxyheptadecyl)-4-oxo-quinazolin-3(4H)yl]-3-phenylthiourea (12). The heating of 12 with malonic acid in acetylchloride produced 3-(2-(1hydroxyheptadecyl)-4-oxoquinazolin-3(4H)-yl)-1phenyl-2-thioxo-dihydropyrimidine-4,6-dione (13).

Finally, compound 8 reacted with benzoylchloride and gave $\mathrm{N}$-(2-(1-hydroxy-heptadecyl)-4 oxoquinazolin$3(4 H)$-yl)benzamide (14). Which was treated by ammonium acetate-acetic acid to give 1-(2-phenyl$[1,2,4]$ triazolo[1,5-c]quinazolin-5-yl)heptadecan-1ol (15).

\subsection{Conversion of the prepared compounds (3-15) to nonionic surfactants (16 -28)}

The structure of the surface active agent requires a hydrophilic part, which is accomplished by condensing the alkylene oxide at active terminal

Table 1

Reaction conditions of propenoxylated compounds

\begin{tabular}{|c|c|c|c|c|c|}
\hline Compds & Catalyst, wt \% & Temperature ${ }^{\circ} \mathrm{C}$ & $\begin{array}{l}\text { Propoxylated } \\
\text { products }\end{array}$ & Yield \% & $\begin{array}{c}\text { Degree of } \\
\text { Propenoxylation } n^{\star}\end{array}$ \\
\hline 3 & & & 16 & $60-55$ & $5-15$ \\
\hline 4 & & & 17 & $60-65$ & $5-15$ \\
\hline 5 & & & 18 & $71-67$ & $5-15$ \\
\hline 6 & & & 19 & $82-78$ & $5-15$ \\
\hline 7 & & & 20 & $72-66$ & $5-15$ \\
\hline 8 & & & 21 & $80-75$ & $5-15$ \\
\hline 9 & $\mathrm{KOH}, 0.01$ wt \% & $120-125$ & 22 & $60-58$ & $5-15$ \\
\hline 10 & & & 23 & $72-66$ & $5-15$ \\
\hline 11 & & & 24 & $72-66$ & $5-15$ \\
\hline 12 & & & 25 & $70-66$ & $5-15$ \\
\hline 13 & & & 26 & $63-59$ & $5-15$ \\
\hline 14 & & & 27 & $67-63$ & $5-15$ \\
\hline 15 & & & 28 & $75-64$ & $5-15$ \\
\hline
\end{tabular}

* Degree of propenoxylation was calculated by weight 
groups. The term nonionic surfactants refers mainly to polyoxypropylene derivatives, and are usually prepared by the addition of different moles ( $n$ ) of propylene oxide $(\mathrm{n} \cong 5,10,15)$ to synthesized products at any active hydrogen atoms $(\mathrm{OH}, \mathrm{NH}$, $\mathrm{NH}_{2}$ ) using $\mathrm{KOH}$ catalyst. The reaction conditions are shown in Table 1.

\subsection{Surface active properties}

The investigation of the surface active properties of the oxypropylated compounds has been done in the neutral medium, at a concentration of $1 \mathrm{wt} \%$ and $25{ }^{\circ} \mathrm{C}$. These types of surfactants are especially interesting because they are not the most common. Therefore the traditional procedure was used to follow up the properties. The results are represented in Table 2.

\subsubsection{Surface and interfacial tension}

The prepared compounds are shown in Table 2. It is evident that the products obtained have pronounced surface activity. In general, the surface

Table 2

Surface properties of nonionic compounds

\begin{tabular}{|c|c|c|c|c|c|c|c|}
\hline Comp. & No. & $\begin{array}{c}\text { Surface } \\
\text { Tension } \\
\text { (dyne/cm) } 0.1 \mathrm{~m} / \mathrm{l}\end{array}$ & $\begin{array}{c}\text { Interfacial } \\
\text { tension } \\
\text { (dyne/cm)0.1 m/l }\end{array}$ & $\begin{array}{l}\text { Cloud } \\
\text { Point } \\
{ }^{\circ} \mathrm{C}\end{array}$ & $\begin{array}{l}\text { Wetting } \\
\text { time } \\
\text { (sec.) }\end{array}$ & $\begin{array}{l}\text { Emulsion } \\
\text { stability } \\
\text { (min.) }\end{array}$ & $\begin{array}{c}\text { Foam } \\
\text { height } \\
(\mathrm{mm})\end{array}$ \\
\hline \multirow[t]{3}{*}{16} & 5 & 33 & 8.0 & 54 & 45 & 120 & 104 \\
\hline & 10 & 36 & 9.5 & 66 & 37 & 92 & 134 \\
\hline & 15 & 40 & 10.5 & 75 & 25 & 80 & 151 \\
\hline \multirow[t]{3}{*}{$\overline{17}$} & 5 & 31 & 10.0 & 67 & 45 & 71 & 95 \\
\hline & 10 & 35 & 13.0 & 67 & 26 & 67 & 120 \\
\hline & 15 & 41 & 16.0 & 91 & 17 & 63 & 140 \\
\hline \multirow[t]{3}{*}{18} & 5 & 32 & 10.0 & 69 & 49 & 125 & 78 \\
\hline & 10 & 36 & 11.0 & 81 & 33 & 96 & 124 \\
\hline & 15 & 40 & 12.5 & 90 & 25 & 76 & 142 \\
\hline \multirow[t]{3}{*}{19} & 5 & 32 & 9.0 & 73 & 53 & 120 & 90 \\
\hline & 10 & 37 & 11.5 & 92 & 37 & 95 & 100 \\
\hline & 15 & 43 & 14.0 & 99 & 26 & 89 & 120 \\
\hline \multirow[t]{3}{*}{20} & 5 & 33 & 8.0 & 70 & 51 & 112 & 97 \\
\hline & 10 & 38 & 9.0 & 87 & 35 & 82 & 128 \\
\hline & 15 & 44 & 11.5 & 98 & 26 & 73 & 148 \\
\hline \multirow[t]{3}{*}{21} & 5 & 37 & 8.0 & 63 & 44 & 96 & 115 \\
\hline & 10 & 34 & 10.0 & 75 & 33 & 88 & 135 \\
\hline & 15 & 32 & 11.5 & 96 & 25 & 78 & 155 \\
\hline \multirow[t]{3}{*}{22} & 5 & 30 & 7.5 & 77 & 43 & 70 & 105 \\
\hline & 10 & 34 & 9.0 & 90 & 31 & 72 & 130 \\
\hline & 15 & 37 & 10.5 & 99 & 20 & 63 & 160 \\
\hline \multirow[t]{3}{*}{23} & 5 & 33 & 10.5 & 67 & 49 & 106 & 89 \\
\hline & 10 & 37 & 12.0 & 83 & 33 & 96 & 110 \\
\hline & 15 & 39 & 13.5 & 94 & 25 & 75 & 130 \\
\hline \multirow[t]{3}{*}{24} & 5 & 35 & 9.0 & 59 & 42 & 95 & 120 \\
\hline & 10 & 38 & 10.5 & 77 & 35 & 85 & 130 \\
\hline & 15 & 40 & 12.0 & 89 & 27 & 70 & 155 \\
\hline \multirow[t]{3}{*}{25} & 5 & 35 & 8.5 & 64 & 47 & 90 & 90 \\
\hline & 10 & 38 & 10.5 & 82 & 36 & 79 & 110 \\
\hline & 15 & 41 & 13.0 & 93 & 25 & 64 & 140 \\
\hline \multirow[t]{3}{*}{26} & 5 & 31 & 7.5 & 76 & 42 & 94 & 118 \\
\hline & 10 & 35 & 9.5 & 86 & 30 & 86 & 138 \\
\hline & 15 & 39 & 10.0 & 97 & 22 & 76 & 158 \\
\hline \multirow[t]{3}{*}{27} & 5 & 31 & 8.5 & 73 & 39 & 110 & 95 \\
\hline & 10 & 36 & 10.5 & 85 & 31 & 98 & 120 \\
\hline & 15 & 39 & 11.5 & 93 & 23 & 80 & 150 \\
\hline \multirow[t]{3}{*}{28} & 5 & 32 & 8.5 & 70 & 43 & 130 & 112 \\
\hline & 10 & 34 & 9.5 & 83 & 31 & 98 & 135 \\
\hline & 15 & 36 & 10.5 & 91 & 20 & 77 & 213 \\
\hline
\end{tabular}

Error was:

Surface and interfacial tensions $= \pm 0.1 \mathrm{dynes} / \mathrm{cm}$

Cloud point

Foam height

Wetting time

$= \pm 1{ }^{\circ} \mathrm{C}$

$= \pm 2 \mathrm{~mm}$

Emulsion

$= \pm 1 \mathrm{sec}$ 
and interfacial tensions increase with an increase in the molecular weight of the hydrophobic moiety. On the other hand, increases by increasing the number of propylene oxide unit cooperated with the molecule. This leads to an increase in the surface activity

\subsubsection{Cloud point}

A very important factor in making the most efficient use of nonionic surfactants in aqueous system is an understanding of the property called cloud point. The data in table 2 show that the cloud point increases by increasing the number of propenoxy groups per hydrophobic molecule. The cloud point of the prepared surfactants is less than $100^{\circ} \mathrm{C}$.

\subsubsection{Wetting time}

For the prepared compounds, it decreased by increasing the moles of propylene oxide in the molecules. At all points of the investigation, the synthesized surfactants were efficient wetting agents. It was found that low propylene oxide content also have the most efficient wetting promoter.

\subsubsection{Foam power}

Foam npower was also investigated for the nonionic compounds and are generally rated as low to moderately foamy. The foam height of the prepared surfactants increases with increasing propylene oxide unit per molecule of surfactant. A low foaming power has an application in the dyeing industry (Somya et al., 1998)

\subsubsection{Emulsion stability}

Studies are still being carried out on the use of surfactants in emulsion formation which is of immense importance to technological development. It was proven that the emulsifying stability of the prepared surfactants especially those containing heterocyclic nucleus exhibit good emulsifying properties and increase by decreasing the number of propylene oxide units. These results might lead to the application of the surfactants of choice in the manufacturing of pesticides and cosmetics.

\subsection{Biodegradability}

The trend of degradation in river die-away tests was followed by the surface tension measurements. The results are given in Table 3 . The rate of degradation of these compounds depends on the size of molecule; bulky molecule diffuses through the cell membrane, and its degradation is more difficult. This means that the molecule with the least moles of propylene oxide are more degradable than that which contains higher moles of propylene oxide.

\subsection{Biological activity}

The results are compiled in Table 4. It has been observed that, most of the synthesized compounds have remarkable antimicrobial activity towards the selected bacteria and fungi. The presence of heterocyclic moiety in the prepared nonionic surfactant molecule revealed an increase in the biological activity. It is therefore clear that these surfactants were effective and inhibited the growth of all tested microorganisms.

\section{CONCLUSION}

From the previous results, one may conclude that all prepared nonionic surfactants have good emulsifier properties in non edible media such as insecticides and, pesticides.

\section{ACKNOWLEDGMENTS}

Origin of cultures: Botany Department, Faculty of Science, Benha University, Egypt.

\section{BIBLIOGRAPHY}

Aly, AA. 2003. Synthesis of novel quinazoline derivatives as antimicrobial agents. Chinese J. Chem. 21, 339346.

Amine MS, Eissa AMF, Shaaban AF, El-Sawy AA, El-Sayed R. 1998. Uses of quinazolin-2[( $\beta$-propionoyl) isothiocyanate]-4-one as a building block in synthesis of some heterocyclic compounds of expected biological activity. Indian. J. Chem. 37B, 1153-1156.

Amine MS, Eissa AMF, Shaaban AF, El-Sawy AA, ElSayed R. 1998. Utilization of 2-(2-carboxyethyl)-4(3H)quinazolinethione in the synthesis of condensed and noncondensed heterocycles. Indian. J. Heterocycl. Chem. 7,4, 289-292.

Amine MS, Eissa AMF, Shaaban AF, El-Sawy AA, ElSayed R. 2004. New heterocycles having double characters as antimicrobial and surface active agents. Part 3: Nonionic compounds from fatty acid hydrazide. Grasas Aceites 53, 124-128.

Amine MS, Eissa AMF, Shaaban AF, El-Sawy AA, ElSayed R. 2004. New heterocycles having a double characters; as antimicrobial and surface active agents. Part 1: Nonionic compounds from fatty acid isothiocyanate. Grasas Aceites. 55, 370-377.

Cansiz A, Kaparir M, Demirdag A. 2004. Synthesis of some new 4,5-substituted-4H-1,2,4-trizole-3-thiol derivatives. Molecules 9, 204-212.

Draves CZ, Clarkso R. 1931. J. Am. Dye Stuff Reporter 20, 201.

Eissa AMF. 2003. Utilites of 2-ethyl-4H-3,1-benzoxazine4-one in synthesis of some interesting heterocyclic compounds. Chemistry: An Indian Journal 1, 17-21.

Eissa AMF, Ahmed, MHM. 2003. Nonionic surface active agents containing heterocyclic moieties. J. Olaj, Szappan, Kozmetika. 52, 11-17.

EI-Sayed R, Wasfy AAF, Aly AA. 2005. Synthesis of novel heterocycles with antimicrobial and surface activity. J. Heterocyclic Chem. 42, 125-130. 
Table 3

Biodegradability of the Prepared Surfactants

\begin{tabular}{|c|c|c|c|c|c|c|c|c|}
\hline Compds. & No. & $1^{\text {st }}$ day & $2^{\text {nd }}$ day & $3^{\text {rd }}$ day & $4^{\text {th }}$ day & $5^{\text {th }}$ day & $6^{\text {th }}$ day & 7th day \\
\hline \multirow[t]{3}{*}{16} & 5 & 51 & 68 & 79 & 84 & 96 & - & - \\
\hline & 10 & 48 & 65 & 74 & 80 & 90 & - & - \\
\hline & 15 & 45 & 61 & 72 & 79 & 85 & 93 & - \\
\hline \multirow[t]{3}{*}{17} & 5 & 49 & 62 & 70 & 97 & 86 & 92 & - \\
\hline & 10 & 46 & 56 & 69 & 72 & 83 & 88 & - \\
\hline & 15 & 40 & 51 & 76 & 70 & 79 & 83 & - \\
\hline \multirow[t]{3}{*}{$\overline{18}$} & 5 & 53 & 65 & 71 & 81 & 93 & - & - \\
\hline & 10 & 48 & 59 & 69 & 77 & 80 & 91 & - \\
\hline & 15 & 45 & 57 & 67 & 74 & 78 & 88 & - \\
\hline \multirow[t]{3}{*}{19} & 5 & 55 & 55 & 62 & 79 & 87 & 90 & - \\
\hline & 10 & 49 & 51 & 59 & 67 & 78 & 88 & - \\
\hline & 15 & 47 & 48 & 57 & 63 & 72 & 85 & - \\
\hline \multirow[t]{3}{*}{20} & 5 & 53 & 58 & 66 & 80 & 82 & 93 & - \\
\hline & 10 & 50 & 56 & 63 & 71 & 79 & 96 & - \\
\hline & 15 & 49 & 54 & 59 & 68 & 95 & - & - \\
\hline \multirow{3}{*}{$\overline{21}$} & 5 & 57 & 62 & 71 & 79 & 85 & 93 & - \\
\hline & 10 & 55 & 57 & 69 & 73 & 83 & 90 & - \\
\hline & 15 & 52 & 52 & 68 & 71 & 79 & 87 & - \\
\hline \multirow[t]{3}{*}{22} & 5 & 48 & 60 & 68 & 78 & 89 & - & - \\
\hline & 10 & 45 & 56 & 66 & 73 & 76 & 98 & - \\
\hline & 15 & 41 & 51 & 64 & 70 & 73 & 80 & - \\
\hline \multirow{3}{*}{$\overline{23}$} & 5 & 49 & 66 & 79 & 89 & 96 & - & - \\
\hline & 10 & 48 & 63 & 73 & 86 & 95 & - & - \\
\hline & 15 & 43 & 59 & 71 & 79 & 88 & 96 & - \\
\hline \multirow[t]{3}{*}{24} & 5 & 50 & 62 & 68 & 79 & 92 & - & - \\
\hline & 10 & 47 & 55 & 63 & 72 & 80 & 93 & - \\
\hline & 15 & 43 & 49 & 45 & 65 & 77 & 91 & - \\
\hline \multirow[t]{3}{*}{25} & 5 & 54 & 54 & 60 & 77 & 80 & 93 & - \\
\hline & 10 & 48 & 52 & 57 & 65 & 76 & 90 & - \\
\hline & 15 & 45 & 49 & 54 & 61 & 73 & 86 & - \\
\hline \multirow[t]{3}{*}{26} & 5 & 55 & 63 & 73 & 82 & 78 & 80 & - \\
\hline & 10 & 52 & 59 & 70 & 75 & 85 & 92 & - \\
\hline & 15 & 49 & 54 & 69 & 73 & 81 & 91 & - \\
\hline \multirow[t]{3}{*}{27} & 5 & 54 & 63 & 73 & 84 & 95 & - & - \\
\hline & 10 & 48 & 55 & 67 & 79 & 92 & - & - \\
\hline & 15 & 45 & 50 & 61 & 72 & 84 & 93 & - \\
\hline \multirow[t]{3}{*}{28} & 5 & 55 & 67 & 75 & 85 & 95 & - & - \\
\hline & 10 & 52 & 59 & 71 & 82 & 92 & - & - \\
\hline & 15 & 50 & 56 & 61 & 75 & 88 & 93 & - \\
\hline
\end{tabular}

Table 4

Response of various microorganisms to nonionic compounds in vitro

\begin{tabular}{|c|c|c|c|c|c|c|c|c|}
\hline \multirow[t]{2}{*}{$\begin{array}{l}\text { Compd. } \\
\text { No. }\end{array}$} & \multicolumn{2}{|c|}{ Bacillus cereus } & \multicolumn{2}{|c|}{ Escherichia coli } & \multicolumn{2}{|c|}{$\begin{array}{l}\text { Aspergillus } \\
\text { niger }\end{array}$} & \multicolumn{2}{|c|}{$\begin{array}{c}\text { Pencicillium } \\
\text { notatum }\end{array}$} \\
\hline & A & $\begin{array}{c}\text { MIC } \\
(\mu \mathrm{g} / \mathrm{ml})\end{array}$ & A & $\begin{array}{c}\text { MIC } \\
(\mu \mathrm{g} / \mathrm{ml})\end{array}$ & A & $\begin{array}{c}\text { MIC } \\
(\mu / \mathrm{ml})\end{array}$ & A & $\begin{array}{c}\text { MIC } \\
(\mu \mathrm{g} / \mathrm{ml})\end{array}$ \\
\hline 16 & + & 250 & - & - & + & 250 & ++ & 125 \\
\hline 17 & + & 125 & + & 250 & ++ & 125 & + & 250 \\
\hline 18 & ++ & 250 & ++ & 250 & ++ & 250 & ++ & 125 \\
\hline 19 & - & 125 & + & 250 & + & 250 & + & 250 \\
\hline 20 & ++ & 250 & - & 125 & - & 125 & ++ & 250 \\
\hline 21 & + & 250 & + & 250 & - & 125 & + & 125 \\
\hline 22 & - & 125 & - & 125 & + & 250 & - & 125 \\
\hline 23 & ++ & 250 & - & 125 & + & 125 & + & 125 \\
\hline 24 & + & 125 & ++ & 250 & +++ & 125 & ++ & 125 \\
\hline 25 & + & 250 & - & 125 & + & 250 & - & 125 \\
\hline 26 & + & 125 & + & 250 & ++ & 125 & + & 250 \\
\hline 27 & + & 250 & - & 125 & + & 125 & + & 125 \\
\hline 28 & + & 125 & ++ & 250 & +++ & 125 & ++ & 125 \\
\hline
\end{tabular}

A; Antimicrobial activity of tested compounds; the width of the zone of inhibition indicates the potency of antimicrobial activity, (-) no antimicrobial activity, $(+)$ week activity with diameter equal to $(0.5-0.7 \mathrm{~cm}),(++)$ moderate activity with the diameter zone equal to $(1.0-1.2 \mathrm{~cm}),(+++)$ marked activity with the (+) week activity with diameter equalp

MIC; Minimum inhibition concentration (different concentrations have been chosen 125, 250, $500 \mu \mathrm{g} / \mathrm{ml}$ ). 
El-Sukkary MA, El-Sawy AA, El-Dib. 1987. Synthetic Detergents from Crude rice bran oil. Hungarian J. Ind. Chem. $15,317-320$.

Eter ET, Richard RE, Darid, A. 1974. Biodegradable surfactants derived from corn starch. J. Am. Oil Chem. Soc. 51, 486-494.

Findly A. 1963. Practical Physical Chemistry, $6^{\text {th }}$ Ed., Longmans, London, p. 1040.

Madkour HMF. 2005. Reactivity of 4H-3,1-benzoxazin-4ones towards nitrogen and carbon nucleophilic reagents: applications to the synthesis of new heterocycles. Arkat USA Inc. 4, 1-17.

Mohamed AS, Mohamed FA, Mohamed AA, AbdelBasset, MS. 2003. Synthesis of novel 3H-quinazolin4-one containing pyrazolinone, pyrazole and pyrimidinone moieties. Molecules 8, 363-373.
Rosen MJ. 1989. $2^{\text {th }}$ Ed., John Wiley \& Sons, New York, pp. 286-294.

Somaya AR, Eissa AMF, Nadia A, Ahmad MN. 1998. Synthesis and characterization of some peptides having surface activity using polyethylene glycol. $J$. Pharm. Sci. 7, 27-32.

Takeshi H. 1970. Studies of ester containing surfactant: Preparation and properties of sodium sulphalkanoates. Bull. Chem. Soc. 43, 2236-2239.

Wiel JK, Smith FD, Stirton AJ, Bistine RG. 1963. Long chain alkanesulphonates and 1-hydroxy-2-alkanesulphonates: Structure and property relations. J. Am. Oil. Chem. Soc. $40,538-541$.

Recibido: Octubre 2005 Aceptado: Mayo 2006 